\title{
Beekeeping in, of or for the city? A socioecological perspective on urban apiculture
}

\author{
Douglas B. Sponsler ${ }^{1,2}$ (D) | Eve Z. Bratman ${ }^{3}$ (D)
}

${ }^{1}$ Department of Animal Ecology and Tropical Biology, Biocenter, University of Würzburg, Würzburg, Germany

${ }^{2}$ Department of Botany, The Academy of Natural Sciences of Drexel University, Philadelphia, PA, USA

${ }^{3}$ Department of Earth \& Environment, Franklin \& Marshall College, Lancaster, PA, USA

\section{Correspondence}

Douglas B. Sponsler

Email: douglas.sponsler@uni-wuerzburg.de

\section{Funding information}

National Institute of Food and Agriculture, Grant/Award Number: 2017-07141

Handling Editor: Arjen Buijs

\begin{abstract}
1. The term 'urban beekeeping' connotes a host of meanings-sociopolitical, commercial, ecological and personal-beyond the mere description of where bees and beekeepers happen to coincide. Yet, these meanings are seldom articulated explicitly or brought into critical engagement with the relevant fields of urban ecology and political ecology.

2. Beginning with a brief account of the history of urban beekeeping in the United States, we draw upon urban ecological theory to construct a conceptual model of urban beekeeping that distinguishes beekeeping in, of and for the city. In our model, beekeeping in the city describes the mere importation of the traditionally rural practice of beekeeping into urban spaces for the private reasons of the individual beekeeper, whereas beekeeping of the city describes beekeeping that is consciously tailored to the urban context, often accompanied by (semi)professionalization of beekeepers and the formation of local expert communities (i.e. beekeeping associations). Beekeeping for the city describes a shift in mindset in which beekeeping is directed to civic ends beyond the boundaries of the beekeeping community per se.

3. Using this framework, we identify and discuss specific socioecological assets and liabilities of urban beekeeping, and how these relate to beekeeping in, of and for the city. We then formulate actionable guidelines for maturing the practice of urban beekeeping into a beneficent and self-critical form of urban ecological citizenship; these include fostering self-regulation within the beekeeping community, harnessing beekeeping as a 'gateway' experience for a broader rapprochement between urban residents and nature, and recognizing the political-ecological context of beekeeping with respect to matters of socioecological justice.
\end{abstract}

\section{KEYWORDS}

environmental justice, honey bee, multispecies studies, policy, pollinator, urban greening

\section{1 | INTRODUCTION}

The most charismatic of mini-fauna, the western honey bee (Apis mellifera L.) has become a cause célèbre of environmentalism, thrust into the role of protagonist in contexts ranging from primary school curricula (Cho \& Lee, 2018) to multinational litigation (e.g. European Food Safety Authority, 2013). The legitimacy of the honey bee as a conservation proxy has been challenged (Colla \& Maclvor, 2017; Geldmann \& González-Varo, 2018), and debate about the attention the honey bee deserves relative to other species continues

This is an open access article under the terms of the Creative Commons Attribution License, which permits use, distribution and reproduction in any medium, provided the original work is properly cited.

(c) 2021 The Authors. People and Nature published by John Wiley \& Sons Ltd on behalf of British Ecological Society 
(Kleijn et al., 2018; Saunders et al., 2018). Our concern here, though, is not with the ecological significance of honey bees as such, but rather with what may be considered an epiphenomenon of the honey bee's prominence in the public imagination: the rise of urban beekeeping and its role in the socioecology of cities.

While urban beekeeping occurs globally in various forms, our discussion will focus primarily on urban beekeeping in the United States. During the urban sanitation efforts of the 1920s (Childers et al., 2014; Grove, 2009), restrictions on urban beekeeping became folded into ordinances prohibiting animal husbandry in cities, and zoning for animal agriculture in cities was almost inconceivable until the 1950s (Brinkley \& Vitiello, 2014). A renewed interest in urban 'homesteading' took off in the early and mid-1970s, but urban beekeeping remained rare. Until the early 2000s, urban beekeeping and livestock ordinances tended to be restrictive, although there remained some variation both between different urban areas, and state or county laws sometimes take precedence over more prohibitive local zoning ordinances (Meenar \& Hoover, 2012).

A significant rise in the number of hobbyist beekeepers-including urban beekeepers-began in the United States around 2008 (Bee Informed Partnership, 2018; USDA-NASS, 2018), likely driven by the media attention garnered by reports of 'colony collapse disorder' (CCD) that began in 2006 (Vanengelsdorp et al., 2009). CCD provided context, curiosity, and urgency, at the same time the public imagination was being sparked by best-selling books that helped to popularize the local food movement (Pollan, 2006; Schlosser, 2012). By 2010, New York and Los Angeles lifted their restrictions on urban beekeeping, with Milwaukee, WI and Washington DC following suit in 2012, creating an influential precedent for cities and municipalities across the country.

Today, urban beekeeping in the United States is an established practice, having outlived the initial media frenzy of the late-2000s that energized its rise from the status of an 'underground' hobby, often in violation of city ordinances, to that of a celebrated urban amenity, often with explicit civic endorsement. Nevertheless, the real socioecological significance of urban beekeeping has yet to be analysed rigorously. Our purpose in writing this perspective article is to begin the task of situating urban beekeeping explicitly within an urban socioecological framework in which its significance can be analysed and interpreted coherently. Using this framework, we explore the socioecological assets and liabilities of urban beekeeping, identify key modulators of these assets and liabilities, and conclude with a prospectus for the future of urban beekeeping and its place with the socioecology of the city.

\section{EXTENDING URBAN ECOLOGICAL THEORY TO URBAN BEEKEEPING}

The history of urban ecology has been summarized in terms of three main paradigms: ecology in, of and for the city (Childers et al., 2014; Pickett et al., 2016). The earliest of these, ecology in the city, conceives of 'terrestrial and aquatic patches within cities, suburbs, and exurbs as analogs of non-urban habitats' (Pickett et al., 2016). The central questions of ecology in the city concern the effect of the urban matrix (e.g. its built environment, impervious surfaces, density of human population, altered climate) on focal patches, and how these urban patches may differ from their non-urban counterparts. Building on the insights of ecology in the city, ecology of the city understands the city as a coupled human-natural system in which social and biogeophysical components are intertwined and mutually constituted, operating in two-way relationships with complex feedback loops (McPhearson et al., 2016; Pickett et al., 2016). Finally, ecology for the city takes on an explicitly transdisciplinary scope, aiming to apply ecological knowledge towards civic ends. In this approach, the aims and assumptions of urban ecology are nested within a broader ethic of sustainability, stewardship and environmental justice (Walker et al., 2004), and knowledge is meant to inform action (Childers et al., 2014). In keeping with these broader normative commitments, ecology of the city seeks genuine collaboration with urban stakeholders and policymakers, and ecologists doing research understand themselves to be embedded, self-critical members of society (Pickett et al., 2016). The ecology for the city paradigm may be recognizable to social scientists as having much in common with the field of political ecology.

We suggest that the in/of/for framework of urban ecological theory can be applied to the analysis of urban beekeeping. Our appropriation of this framework is intended as a heuristic strategy rather than a univocal use of the original formulation (Childers et al., 2014; Pickett et al., 2016). Nevertheless, insofar as urban beekeeping is an urban ecological phenomenon, an amalgam of natural processes with the human intricacies of the city, its relationship to urban ecological theory is far from merely nominal.

\section{3 | BEEKEEPING IN THE CITY}

The key distinction of ecology in the city is that the urban landscape is seen as a context in which ecology occurs but not necessarily as an integrated ecological system. In the same sense, beekeeping in the city describes the practice of urban beekeeping that is only incidentally rather than constitutively urban. It occurs in the city but neither takes on a distinctly urban form integrated with the social and ecological context of the city nor serves any explicit socioecological agenda beyond the relationship between bees and beekeeper. Beekeeping in the city should not, for these reasons, be dismissed as trivial, but the key trait of beekeeping in the city is the private scope of its explicit significance: a unique, and at times profound, relationship between a person (the beekeeper) and a managed-yet-still-wild animal. The socioecological impacts, positive or negative, of such beekeeping are not null for being non-explicit, but they are externalities, in the economic 
sense of the word, with respect to the explicit exchange between bees and beekeeper.

\section{4 | BEEKEEPING OF THE CITY}

Beekeeping of the city occurs when the practice of beekeeping is transformed by the exigencies of the urban context into a distinct trade, functionally integrated into the life of the city, yet not necessarily attached to any explicit socioecological agenda. This form of beekeeping is most apparent in (though not limited to) the subset of urban beekeepers (in most places, a small one) for whom beekeeping is a significant economic activity. The beekeeper is, by practical necessity, aware that beekeeping is contextualized by the ecology of city. The health and productivity of a honey bee colony hinges on the composition and dynamics of the local floral community, on regional weather and climate, and-significantly-on the decisions of neighbouring beekeepers with respect to colony density and pest/pathogen management. Moreover, the beekeeper understands that the economic viability of beekeeping is intertwined with the economy of the city: the buying power of different human demographics, the trends in consumer interest in apicultural goods and services, the approach of consumers via marketing strategies. Beekeepers of the city become an expert community, a trade guild, with special knowledge of and interest in the socioecology of the city, at least insofar as it pertains to their beekeeping. The inverse of this relationship, however-the impact of beekeeping on the socioecology of the city beyond the immediate exchanges between the beekeeping operation and the urban contextremains an externality.

\section{5 | BEEKEEPING FOR THE CITY}

Beekeeping can be said to be for the city when the socioecological impact of beekeeping, heretofore an externality, becomes an explicit objective. Beekeepers for the city understand their beekeeping as a form of environmental and social activism, of participation in the life of the city as such, a practice of ecological citizenship (Light, 2003). Beekeeping for the city can be understood as a practice of re-imagining the place of nature in urban life ways through the practice of interspecies relationships. This is, perhaps, the most conspicuous form of urban beekeeping in the public imagination because its practice is public by design, often accompanied by outspoken advocacy and invitation to participation. Its ethos is articulated well by geographer Jennifer Wolch: 'we bring the bee into the urban landscape for intellectual, ecological, and moral reasons to re-imagine the anima Urbis-the breath, life, soul, and spirit of the city-as embodied in its animal life' (Wolch, 2002). However, while emphasizing the normative agenda of beekeeping for the city, it is important to remember that socioecological zeal does not equal socioecological competency. In its most specious (and, alas, not uncommon) forms, beekeeping for the city indulges in the fallacy that by merely stocking one's backyard with honey bee colonies, one will 'save' bees, the city or both (Alton \& Ratnieks, 2016).

\section{6 | SOCIOECOLOGICAL ASSETS AND LIABILITIES OF URBAN BEEKEEPING}

The three forms of urban beekeeping we suggest-beekeeping in, of and for the city-are not mutually exclusive, nor do they form a straightforward gradient of socioecological value. Instead, they interact in complex ways with a suite of potential socioecological assets and liabilities, and the realized value of urban beekeeping in the life of the city depends on how these assets and liabilities are managed. We argue that the degree to which these assets and liabilities are recognized, and the decisions made with respect to inevitable trade-offs between them, hinge in part on where beekeepers fall along the in/of/for continuum.

\section{7 | POLLINATION SERVICES}

The majority of flowering plants are fully or partially dependent on animal pollinators for fruit and seed production (Ollerton et al., 2011), and bees are by far the most important group of pollinators (Willmer et al., 2017). While wild bees and other insect pollinators account for a substantial portion of the pollination often attributed to managed honey bees (Garibaldi et al., 2013), the honey bee has special value as a pollinator due to its global distribution and amenability to human management. The importance of the honey bee as a pollinator in urban landscapes, however, is virtually unstudied, and probably varies markedly across specific urban contexts. One cannot assume that the addition of honey bees to a landscape will improve pollination services to crops or wild plants without first establishing that (a) a deficit of pollination services exists and (b) honey bees serve as pollinators for the plants of concern (Melathopoulos et al., 2015). Even where these conditions hold, the conventional monetary valuation of honey bee pollination services would be of uncertain relevance in urban systems where pollination is not as consistently linked to the sale of produce. Nevertheless, it is likely that many plants in urban localities benefit from honey bee pollination, and this service, though poorly studied and difficult to quantify, is rightly recognized as a legitimate asset of urban beekeeping. Where beekeeping can be strategically integrated into the production of pollinator-dependent crops in urban agricultural systems, it has the potential to become uniquely of and for the city, functioning as part of an interconnected social, ecological and technological system (SETS), a stewarded interconnection between social and natural worlds (Cousins, 2018; Markolf et al., 2018).

\section{8 | RESOURCE COMPETITION}

The mutualism between plants and pollinators is often portrayed as a sort of ecological sacrament; yet, it is also a material exchange of finite resources. Plants share a finite pool of pollinator visitation while pollinators share a finite pool of floral nectar and pollen, and sharing becomes competition when either resource is limiting. There 
is a growing empirical evidence that, at sufficient density, honey bees competitively limit local wild bees (e.g. Henry \& Rodet, 2018). The generality and severity of this phenomenon in urban areas remains uncertain (McCune et al., 2019; Ropars et al., 2019), but it is important to note that competition need not be constant or even frequent to be influential, since one lean year in ten might be sufficient to drive local extinctions that would persist unless reversed by immigration (MacArthur, 1984). Honey bee colonies also compete with one another (Henry \& Rodet, 2018), and this has, anecdotally, become a problem for beekeepers in cities such as London and New York, where the popularity of urban beekeeping has led to dramatic increases in colony density (Alton \& Ratnieks, 2016; Nessen, 2012). We would suggest that the potential problem of resource competition is most likely to be recognized by beekeepers of and for the city, due to their awareness of the landscape context of their beekeeping, their involvement with other beekeepers and-in the case of beekeepers for the city-their broader civic concern. Beekeepers in the city may be less sensitive to the issue due to the private scope of their beekeeping. As a caveat, though, it is likely that less savvy expressions of beekeeping for the city, in which enthusiasm for urban beekeeping obscures other ecological considerations, are to blame for excess colony density in some cities.

\section{9 | DISEASE TRANSMISSION TO OTHER INSECTS}

Honey bees are afflicted by a host of viral, bacterial and fungal pathogens (Evans \& Schwarz, 2011). Traditionally, these maladies have tended to be characterized as 'honey bee diseases', but recent research has revealed that many of these pathogens can infect other insect species and that managed honey bees might serve as a reservoir and vector of disease for wild bees (Graystock et al., 2016). The significance of this effect remains poorly understood (Mallinger et al., 2017), but it is likely that the risk of disease transmission between honey bees and wild bees depends largely on honey bee colony density, raising concerns that increasing colony density in cities driven by the popularity of urban beekeeping (Alton \& Ratnieks, 2014) may compromise the potential of urban habitats for wild bee conservation (Hall et al., 2017). Moreover, whatever uncertainty may remain with respect to the transmission of disease between honey bees and non-Apis bees, there is no doubt that honey bees transmit pathogens to each other (e.g. Peck \& Seeley, 2019). All types of beekeepers, in proportion to the seriousness of their beekeeping, are sensitive to the issue of disease transmission between honey bee colonies, and this can sometimes be a cause of strife among neighbouring beekeepers who disagree on approaches to colony health management. The potential threat to other insects posed by honey bee diseases is a relatively new research finding not yet widely recognized among beekeepers, though it might be expected that this concern would resonate most with beekeepers for the city due to their sensitivity to the external impacts of their beekeeping.

\section{STINGING}

Bans on urban beekeeping are typically motivated by concerns for public safety (Moore \& Kosut, 2013). Honey bee venom has evolved to cause pain, not injury, in vertebrates (Schmidt, 2014), but for approximately $0.15 \%-0.8 \%$ of children and $0.5 \%-7.5 \%$ of adults, insect stings can induce systemic allergic reactions that are potentially life threatening (Bilò \& Bonifazi, 2008). Thus, minimizing the risk of stings needs to be a top priority when keeping bees in densely populated areas. Honey bees ordinarily sting only in the immediate vicinity of their hive, usually in response to some form of disturbance. Nevertheless, the risk of bystanders being stung needs to be taken very seriously when evaluating the propriety of beekeeping in any particular urban context.

For beekeepers themselves, however, stings are routine and should not be regarded as problematic. Indeed, getting stung is considered by most beekeepers to be a constitutive part of the beekeeping experience: a reminder, perhaps, that the relationship between a beekeeper and a honey bee colony is one of a human and a wild animal, not of an owner and a pet. It 'forces you to take a deep breath, and be present' said one leader of a workshop on the social impact of bees at the World Beekeeping Congress in the fall of 2019. Philadelphia beekeeper Kirk Wattles described the experience of getting stung in even more overtly philosophical terms:

"I think it's definitely part of the social dimension of beekeepingwhat we tell ourselves, and what we tell others, etc. With all the 'telling', though, I realized at one point that a bee sting is also a brush with reality, piercing the veil, not just words and stories, and for me that gives it an interesting philosophical dimension. The randomness also is a factor."

The relationship stinging risk and our in/of/for framework is complex. The likelihood of non-beekeepers being stung is essentially a function of (a) how closely non-beekeepers interact with honey bee colonies and (b) the decisions beekeepers make regarding how and when to manipulate their colonies. For beekeepers in the city, whose activities tend to be private and small scale, minimizing sting risk consists primarily of prudent hive placement and cautious colony management strategies that minimize colonies' defensive behaviour (Garbuzov \& Ratnieks, 2014; Melathopoulos et al., 2018). These considerations intensify for beekeepers of the city, since they typically have more colonies, often at more than one location, and engage in more involved forms of colony management, such as moving colonies between locations. For these beekeepers, the use of warning signage becomes especially important, since it is likely that members of the public will stumble upon apiaries in the beekeeper's absence. The risk of non-beekeepers being stung is maximized in the context of beekeeping for the city, since it often involves keeping bees in very public settings and inviting nonbeekeepers to participate. In these cases, the constitutive nature of getting stung while beekeeping needs to be communicated clearly to participants, who are, in effect, being asked to join beekeepers in appreciating-or at least tolerating-sting risks as a part of the beekeeping experience. 


\section{1 | APICULTURAL PRODUCTS AND LIVELIHOODS}

While there are no reliable data on the gross economic significance of urban beekeeping, urban beekeepers market their trade in a variety of ways. These include the sale of hive products (e.g. honey, wax, pollen, propolis) and their derivatives, the contracted management of hives on behalf of individuals or businesses, and the capture and removal of unwanted swarms or feral colonies. For most, these economic outlets are minor sources of income, but there are some cases of urban beekeepers for whom apiculture is a true livelihood, and sometimes even a source of employment for others. At a corporate level, the Boston-based Best Bees Company offers contracted beekeeping services in several metropolitan areas across the United States, with employees in all those locations. Many similar businesses operate at a local scale, such as the Philadelphia Bee Company, the Chicago Honey Co-Op or the Bay Area Bee Company.

A distinct but related consideration of urban socio-ecological value concerns the significance of hive products as a unique reflection of the neighbourhoods from which they come. Localization of food consumption and alternative food practices, such as shopping at farmer's markets, are often heralded as practices that foster community cohesion through the communal and relational experiences they offer. A sense of local pride in community-based relationships, a lighter environmental footprint and a resistance to the distancing of the global food system may accompany such measures and be wrapped up in the symbolism of buying and eating locally. A word of caution is also merited, though; like community gardening and the creation of new parks, beekeeping and the consumption of microlocal honeys that fetch very high market prices may involve both a symbol and practice of 'sustainability lifestyles' that tend to accompany green gentrification (Checker, 2011; Gould \& Lewis, 2016). Unwittingly, such practices may entrench rather than mitigate the racialized socioeconomic inequalities that characterize cities and neighbourhoods.

At first, it might seem that neither the economic nor the social significance of apicultural products would be of much relevance for beekeeping in the city, but this would overlook the crucial phenomenon-in our experience, practiced by most beekeepers-of giving away honey to neighbours. The practice has been explicitly recommended to urban beekeepers as a form of apicultural diplomacy towards neighbours who might be uncomfortable with having hives in their vicinity (Melathopoulos et al., 2018). But aside from this merely propitiatory function, giving honey creates opportunities for initiating and deepening neighbour relations, quite apart from any conscious purpose of 'civic engagement' on the part of the beekeeper. The economic value of hive products is likely to be appreciated most by beekeepers of the city, particularly the subset of them for which the marketing of hive products yields significant income, whereas the social significance of hive products as representations of neighbourhoods falls squarely within the civic agenda of beekeeping for the city, where it dovetails with other aspects of urban political ecology.

\section{2 | EXPERT COMMUNITY FORMATION AND ECOLOGICAL RAPPROCHEMENT}

To the extent that beekeeping is undertaken seriously, the beekeeper becomes an entomologist, a botanist and an ecologist. At the most obvious level, a beekeeper learns the biology of honey bees. A competent beekeeper, though, also knows the local floral community and its seasonal phenology well enough to plan colony management around the timing of nectar flows (periods of high honey production) and dearths, possibly with the goal of producing high-value varietal honeys from known floral sources. Such knowledge amounts to an ecological understanding of the relationships between bees, plants and the abiotic conditions that contextualize them in a given locality: a form of expertise that, especially in predominantly (though not completely) 'post-agrarian' milieu of urban society, is virtually endemic to the urban beekeeping community. Unique opportunities thus arise for beekeepers to engage ecological issues beyond the immediate scope of their beekeeping (Maderson $\&$ Wynne-Jones, 2016). As urban beekeeping moves in the direction of beekeeping of and for the city, beekeepers also become environmental educators via their engagement (whether purposeful or incidental) with the general public. A beekeeper from Ontario who runs a business setting up honeybee hives on others' private land articulated this quite clearly:

"We make beekeeping a possibility for private landowners who have no desire to be a beekeeper, but they're well aware of the issues facing this planet, the bees, the land, etc. [...] So while we started out with [...] honeybees being the main sort of service that we offer our clients, we find ourselves more and more in a position of being advisors [...]. So our business has taken a very interesting direction in the sense that we do advise on how you can convert, say, a [...] farmer who is spraying his or her crops. It's a critical story about bringing land back to sort of its natural state, about the importance of hedgerows, the importance of native pollinators."

In our first-hand experience of working with urban beekeepers in Philadelphia, we can attest that one can scarcely make it through a day of urban beekeeping without becoming engaged in conversations with interested bystanders, and these conversations frequently extend well beyond the beekeeping at hand to broader topics of plants, pollinators and urban ecology.

When the expertise catalysed by beekeeping spreads beyond the individual beekeeper through the sharing of knowledge and experience with the larger community, beekeeping becomes a source of ecological literacy (Orr, 1990) and potentially ecological citizenship (Light, 2003), with honey bees serving as mediators between people and place. We summarize this with the term 'ecological rapprochement', borrowing the language of political reconciliation to capture the sense of reconstituting the relationship between people and nature (acknowledging that a strict distinction between people and nature is, itself, problematic) amid the artifice of urban landscapes (sensu Kohák, 1984). Ecological rapprochement is fostered when beekeeping is both of and for the city. The former is necessary for the cultivation of local ecological expertise through beekeeping that 
appreciates the city as its ecological context. The latter offers the impetus for public engagement in learning about local urban ecologies, and co-creating ecological conservation or restoration efforts with community members (Turo \& Gardiner, 2019).

\section{3 | GUIDELINES FOR MATURING URBAN BEEKEEPING}

Given the potential assets and liabilities of urban beekeeping, and their sensitivity to urban beekeeping form as described by our in/of/for framework, we suggest several guidelines for maximizing the socioecological value of urban beekeeping. Technical best practices for urban beekeeping have been discussed comprehensively elsewhere (Melathopoulos et al., 2018). Instead, we focus more generally on attitudes and collective strategies, the goal of which is to facilitate the maturation of urban beekeeping from an experimental cultural movement to a self-critical, organized, purposeful and beneficent form of ecological citizenship.

\section{4 | FOSTER SOCIAL ACCOUNTABILITY AND SELF-REGULATION}

With respect to the goal of a 'mature' urban beekeeping, social accountability and self-regulation are not only ends in themselves but also the means to other ends. Thus, we begin our discussion with this question: beyond the binary language of 'banning' and 'legalizing', a policy framework that essentially recognizes only beekeeping in the city, how can reasonable and beneficent norms for urban beekeeping be developed and enforced?

By way of illustration, consider the issue of colony density, which is a key modulator of the potential negative impacts of urban beekeeping, such as resource competition and pest/pathogen transmission. Colony density, as an object of top-down regulation, poses a serious conundrum, since it is a phenomenon that, akin to the issue of nonpoint-source pollution, emerges as the cumulative product of many individual decisions. Insofar as honey bee colonies are treated as semi-regulated private property, there is little a municipal government can do to limit colony density aside from limiting the number of colonies that can be kept on a given parcel of land. Since urban land parcels are small and densely packed, the link between parcel-level apiary size and landscape-level colony density is tenuous. It has been suggested that, at a regional scale, apiary spacing rather than colony density should be the object of regulation, since this approach could maintain low-competition zones in the interstices of the foraging radii of neighbouring apiaries while allowing individual apiaries to operate at a commercially viable scale (Henry \& Rodet, 2020). This approach is ill-suited for urban environments, though, because the spacing required to leave appreciable competition gaps between neighbouring apiaries (>2 km) (Henry \& Rodet, 2020) would either exclude the majority of beekeepers or force a degree of spatial consolidation that would result in impractically large urban apiaries.
Moreover, for most urban beekeepers, the question of apiary location is a moot point, since their own rooftops or backyards are the only spaces they have at their disposal. Thus, one can envision scenarios in which, for lack of more nuanced options, municipalities concerned with excess colony density-perhaps even moved by the same environmental sympathies that catalysed the legalization of urban apiculture-would consider reverting to a simple beekeeping ban.

While affirming a potential role for civic ordinances, we suggest that both the onus and the capacity-and, indeed, the awareness and motivation-for regulating urban beekeeping are to be found primarily within the beekeeping community itself. Drawing on the in/of/for framework, a basis for self-regulation might be found in a marriage of the 'trade guild' qualities of beekeeping of the city with the civic consciousness of beekeeping for the city. Indeed, the word 'guild', with its rich (though checkered) history of training, organizing and regulating skilled communities, has been adopted explicitly by some urban beekeeping groups, including the Philadelphia Beekeepers Guild (PBG). In response the question of regulating colony density in cities, Kirk Wattles, a member of the PBG, remarked:

"For me, these discussions are in the framework of the word 'guild'. We're not simply a 'club' or an 'association' [...]. Guilds set the standards, and historically they also tried to control entry into the trade, in order to reduce numbers and boost prices. The PBG doesn't really try to do that, and we couldn't if we wanted to, but I think there are ways we can model good practices and help people understand the responsibilities."

A modern precedent for such self-regulation of a trade community is, in fact, already known to many beekeepers. In response to health problems in honey bee colonies pollinating almond orchards, the California Almond Board-an association of professional almond growers-developed a set of pesticide use 'best practices' more stringent and context-tailored than regulations imposed by the U.S. Environmental Protection Agency (USEPA) or state-level authorities (Sponsler et al., 2019).

In summary, a mature urban beekeeping is one in which both the decision to become a beekeeper and one's practices as a beekeeper occur within a well-integrated social fabric of support and accountability. From this starting point, beekeeping in and of the city can pursue, with competence and cohesion, the greater goods envisioned by beekeeping for the city.

\section{5 | PRIORITIZE ECOLOGICAL RAPPROCHEMENT}

For city-dwellers, beekeeping has become a medium by which the ecological order of plant-pollinator relationships and conservation become tangible, accessible, and knowable, over-against the thick layer of artifice that intervenes between people and place in the built environment (Kohák, 1984; Lorenz \& Stark, 2015). This restoration of immediacy and interdependency between people and nature is the effect we described earlier with the term 'ecological 
rapprochement'. Drawing again upon our in/of/for framework, the scope of this significance of urban beekeeping can vary. Beekeeping in the city can mediate ecological rapprochement for the individual beekeeper, and secondarily for friends, family and neighbours. Beekeeping of the city grounds this rapprochement in a more concrete understanding of the ecological interactions between honey bees and the urban environment, and fosters rapprochement in the context of a skilled community. Beekeeping for the city intentionally propagates ecological rapprochement beyond the beekeeping community, understanding that the rooftop and backyard husbandry of a semi-wild animal and the city-wide stewarding of its intricate ecological corollaries are radically symbolic of the transition from a 'sanitary' to a 'sustainable' paradigm of what a city should be (Childers et al., 2014).

The concept of ecological rapprochement through beekeeping is illustrated in the work of Vancouver-based non-profit organization Hives for Humanity, which was co-founded by the mother-daughter team Julia and Sarah Common. Sarah Common describes the origins of their work:

"I was in foods and in community, and people were asking how we can get more involved in our food, so they came to a garden. And then in that garden, people were asking how we can bring more people into the garden and how we can create more connection in that garden. And then, that coincided with the conversation I had with my mother, who's been beekeeping for 40 plus years. [...] So you know, connecting to myself and to some of my agency and to my connection to nature and who I am; that really has been through the bees for me and in my life, like from 26 to 34 now, and connecting to my mom through that and understanding, you know, who we are together and who she is beyond provider and parent. And also connecting to my city and understanding what the land we're on there, and who the people who were there before and what the waters mean, and what the forest means has all been through the bees for me. And that's really what I continue to try and support through these is connection to community to nature unto itself."

The organization Bee City USA, which advocates for bee-friendly city ordinances, presents another instance of urban beekeeping as a vehicle for broader ecological action. While the organization is agnostic on the question of whether cities should encourage beekeeping, many Bee- City-affiliated municipalities have urban beekeepers spearheading their campaigns, the aims of which extend explicitly beyond honey bees and beekeeping 'in recognition that the world's $20,000+$ species [of bees] are our planet's pollinator workhorses'. In keeping with this scope, the organization holds that all beekeeping ordinances should be developed 'on a scale and in a fashion that is safe, considerate of others and appropriate to areas of greater population density' while requiring that any official 'bee city' should establish a pollinator advocacy committee, adopt pollinator-conscious practices into city policies and plans and host events for pollinator awareness.

It is also worth noting that even when urban beekeepers drop out of beekeeping, their beekeeping experience may be an entry point into broader ecological stewardship. As one beekeeper observed:

"Backyard beekeepers are finding their way back to native pollinators and native plants, and really a more sustainable way to garden. [...] It seems like through honey bees, I certainly see transformations in what people are doing. I mean, I see more native plants in beekeepers' gardens, and I see them trying to support native pollinators, even to the extent that it's really hard for backyard beekeepers, who eventually will give up honey bees, but continue supporting native populations, which is really encouraging."

We suggest that one mark of a 'mature' urban beekeeping community is the conscious embrace of ecological rapprochement. There is a danger, however, of this understanding devolving into a casual vagueness in which the feeling of 'connecting to nature' becomes a substitute for real knowledge and responsibility. Such decay can be stemmed in part through accountability within the beekeeping community, as discussed above, but we would also underscore the importance of fostering dialogue and accountability between beekeepers and other urban communities of ecological expertise, such as urban naturalists and urban farmers. Through such interchange, the 'gateway' of urban beekeeping becomes a two-way street in which the general sense of ecological rapprochement awakened by beekeeping becomes populated with the concrete particulars of botany, entomology and agriculture, which, in turn, feed back into how beekeeping is understood and practiced.

\section{6 | MAKE EXPLICIT THE POLITICAL ECOLOGY OF URBAN BEEKEEPING}

Urban beekeeping exists not in a vacuum but in a complex political-ecological context, and the socioecological beneficence of urban beekeeping depends on making this context explicit and engaging it wisely. Specifically, little attention has been paid to the question of how the socioecological value of beekeeping is distributed across the dramatic mosaics of inequality that characterize American cities, with their underpinnings of racialized politics. To the extent that this question is ignored, urban beekeeping is liable to become a practice associated with green gentrification (Checker, 2011). Indeed, urban beekeeping is susceptible to the same pitfalls as other forms of urban agriculture and urban greening insofar as it may fail to address deeper social rifts and may ultimately reproduce rather than remedy economically and racially entrenched inequalities (Gould \& Lewis, 2016; Rosan \& Pearsall, 2017). And, as we have argued above, this risk is likely to be highest precisely when urban beekeeping takes on a civic agenda under the form of beekeeping for the city. As in so many things, capacity for good and for harm increase in proportion to one another.

Some lessons from the broader field of urban greening and conservation may be instructive for urban apiculture. Co-creating the goals of urban greening efforts is essential so that efforts align with ecological principles and priorities but also with the needs 
of specific neighbourhoods and communities of residents (Turo \& Gardiner, 2019). An exemplary model for beekeepers is Chicago's 'Roots and Routes' initiative, which protected migratory bird habitat while creating local gathering spaces and opportunities for youth engagement and employment. The programme's success derived from local partnerships, a community design competition and two decades of participatory action research (Montambault et al., 2018). Urban beekeepers who might draw upon such a model must consider the desires and designs of the neighbourhood in which the beekeeping community is situated, engaging iteratively with neighbours to develop beekeeping approaches (e.g. artistic hive designs, job opportunities, landscaping and social space designs, community events) that fit the needs and desires of the neighbourhood. Such outreach must occur not only prior to the establishment of beehives but also as an ongoing praxis of consultation and co-creation. In this way, beekeeping can be not merely in a city, but of and for the neighbourhoods in which it is practiced. Examples of such justice-oriented beekeeping already exist. In Detroit, a group called SWBeetroit is growing a cooperative business while overtly centring Black, Indigenous and People of Color (BIPOC). In the same city, the non-profit organization Detroit Hives is raising bees while restoring blighted city lots and educating local youth about pollinators and beekeeping (Kleiber, 2020).

In all these efforts, care must also be taken to identify and remove barriers to participation within the beekeeping community itself. In this regard, the deep history and global distribution of apiculture can be a powerful catalyst. While beekeeping in the United Sttaes, with its strong ties to European immigrants, tends to be associated with White and male demographics, this belies the fact that beekeeping is a profoundly cosmopolitan practice, with both ancient and extant traditions, often transcending gender boundaries, found throughout the honey bee's native range of Africa, Asia and Europe (Crane, 1999). By celebrating this history of diversity in beekeeping and bringing this history to bear upon the racialized and gendered inequalities of today, urban beekeepers (indeed, all beekeepers) can make their craft constitutively, not just incidentally, inclusive.

\section{7 | CONCLUSION}

Our aim in this paper has been to examine in the clearest possible socioecological terms what urban beekeeping is, what it is not, and what it could be. The in/of/for framework we propose, borrowed from urban ecological theory (Childers et al., 2014; Pickett et al., 2016), sets an agenda for ongoing conversation, and the assets and liabilities we identify, together with the prospectus we derive from them, can inform both practitioners and policymakers. In general, our analysis favours beekeeping for the city, coupled with the expertise that characterizes beekeeping of the city. Importantly, though, we do not wish to dismiss the value of beekeeping in the city for individual beekeepers, and we emphasize that this value can and should be maintained when beekeeping takes on the additional qualities of being of and for the city.

We would encourage future explorations of urban beekeeping to commit to the hard work of transdisciplinarity, for it is evident in our analysis that the disciplinary purviews that converge upon the phenomenon of urban beekeeping are individually insufficient for the task of understanding and adaptively managing the complex relationship between honey bees and people in cities. For an exemplary analysis focused on urban beekeeping in Berlin, we refer our readers to Lorenz and Stark (2015).

Aside from its intrinsic significance, urban beekeeping constitutes a valuable 'model system' for the study of human-nature relationships (Lorenz \& Stark, 2015), particularly within the emergent paradigm of multi-species environmental humanities (Dooren et al., 2016). Moreover, while managed honey bees per se may not be a conservation priority in the traditional sense (Colla \& Maclvor, 2017), the negotiation of their place as a semi-wild animal within anthropogenic landscapes can inform the broader agenda of reconciliation ecology (Rosenzweig, 2003) that seeks to achieve conservation through exactly the sort of ecological rapprochement that urban beekeeping catalyses.

\section{ACKNOWLEDGEMENTS}

We thank D. Shump for invaluable conversation and for generous access to his urban beekeeping operation, and members of the Environments reading group at Franklin \& Marshall College for their feedback on an early version of this paper. Two anonymous reviewers provided helpful feedback on an earlier version of this manuscript. Open Access funding enabled and organized by Projekt DEAL.

\section{CONFLICT OF INTEREST}

Both authors are or have been urban beekeepers, have worked closely with urban beekeepers and have personal friends who are urban beekeepers.

\section{AUTHORS' CONTRIBUTIONS}

Both authors conceived the project and wrote the paper. E.Z.B. carried out the ethnographic field work from which the included interview quotes were drawn.

\section{DATA AVAILABILITY STATEMENT}

No data were used in this paper.

\section{ORCID}

Douglas B. Sponsler (iD) https://orcid.org/0000-0002-4892-9332

Eve Z. Bratman (iD https://orcid.org/0000-0002-0250-446X

\section{REFERENCES}

Alton, K., \& Ratnieks, F. (2014). To bee or not to bee. The Biologist, 60, 12-15.

Alton, K., \& Ratnieks, F. (2016). Roof top hives: Practical beekeeping or publicity stunt? Bee World, 93, 64-67. https://doi.org/10.1080/00057 72X.2016.1257462

Bee Informed Partnership. (2018). National management survey. https:// beeinformed.org/citizen-science/loss-and-management-survey/ 
Bilò, B. M., \& Bonifazi, F. (2008). Epidemiology of insect-venom anaphylaxis. Current Opinion in Allergy and Clinical Immunology, 8, 330-337. https://doi.org/10.1097/ACI.0b013e32830638c5

Brinkley, C., \& Vitiello, D. (2014). From farm to nuisance: Animal agriculture and the rise of planning regulation. Journal of Planning History, 13, 113-135. https://doi.org/10.1177/1538513213507542

Checker, M. (2011). Wiped out by the 'greenwave': Environmental gentrificationand the paradoxical politics of urban sustainability. City\& Society, 23, 210-229. https://doi.org/10.1111/j.1548-744X.2011.01063.x

Childers, D. L., Pickett, S. T. A., Grove, J. M., Ogden, L., \& Whitmer, A. (2014). Advancing urban sustainability theory and action: Challenges and opportunities. Landscape and Urban Planning, 125, 320-328. https://doi.org/10.1016/j.landurbplan.2014.01.022

Cho, Y., \& Lee, D. (2018). 'Love honey, hate honey bees': Reviving biophilia of elementary school students through environmental education program. Environmental Education Research, 24, 445-460. https://doi.org/10.1080/13504622.2017.1279277

Colla, S. R., \& Maclvor, J. S. (2017). Questioning public perception, conservation policy, and recovery actions for honeybees in North America. Conservation Biology, 31, 1202-1204. https://doi.org/10.1111/cobi.12839

Cousins, J. J. (2018). Remaking stormwater as a resource: Technology, law, and citizenship. Wires Water, 5, e1300.

Crane, E. (1999). The world history of beekeeping and honey hunting (1st ed.). Routledge. https://doi.org/10.4324/9780203819937

European Food Safety Authority. 2013. EFSA guidance document on the risk assessment of plant protection products on bees (Apis mellifera, Bombus spp. and solitary bees). EFSA Journal, 11, 3295.

Evans, J. D., \& Schwarz, R. S. (2011). Bees brought to their knees: Microbes affecting honey bee health. Trends in Microbiology, 19, 614620. https://doi.org/10.1016/j.tim.2011.09.003

Garbuzov, M., \& Ratnieks, F. L. W. (2014). Lattice fence and hedge barriers around an apiary increase honey bee flight height and decrease stings to people nearby. Journal of Apicultural Research, 53, 67-74. https://doi.org/10.3896/IBRA.1.53.1.06

Garibaldi, L. A., Steffan-Dewenter, I., Winfree, R., Aizen, M. A., Bommarco, R., Cunningham, S. A., Kremen, C., Carvalheiro, L. G., Harder, L. D., Afik, O., Bartomeus, I., Benjamin, F., Boreux, V., Cariveau, D., Chacoff, N. P., Dudenhöffer, J. H., Freitas, B. M., Ghazoul, J., Greenleaf, S., ... Klein, A. M. (2013). Wild pollinators enhance fruit set of crops regardless of honey bee abundance. Science, 339, 1608-1611. https:// doi.org/10.1126/science.1230200

Geldmann, J., \& González-Varo, J. P. (2018). Conserving honey bees does not help wildlife. Science, 359, 392-393. https://doi.org/10.1126/ science.aar2269

Gould, K. A., \& Lewis, T. L. (2016). Green gentrification: Urban sustainability and the struggle for environmental justice. Routledge. https://doi. org/10.4324/9781315687322

Graystock, P., Blane, E. J., McFrederick, Q. S., Goulson, D., \& Hughes, W. O. H. (2016). Do managed bees drive parasite spread and emergence in wild bees? International Journal for Parasitology: Parasites and Wildlife, 5, 64-75. https://doi.org/10.1016/j.ijppaw.2015. 10.001

Grove, J. M. (2009). Cities: Managing densely settled Social-Ecological systems. In C. Folke, G. P. Kofinas, \& F. S. Chapin (Eds.), Principles of ecosystem stewardship: Resilience-Based natural resource management in a changing world (pp. 281-294). Springer.

Hall, D. M., Camilo, G. R., Tonietto, R. K., Ollerton, J., Ahrné, K., Arduser, M., Ascher, J. S., Baldock, K. C. R., Fowler, R., Frankie, G., Goulson, D., Gunnarsson, B., Hanley, M. E., Jackson, J. I., Langellotto, G., Lowenstein, D., Minor, E. S., Philpott, S. M., Potts, S. G., ... Threlfall, C. G. (2017). The city as a refuge for insect pollinators. Conservation Biology, 31, 24-29. https://doi.org/10.1111/cobi.12840

Henry, M., \& Rodet, G. (2018). Controlling the impact of the managed honeybee on wild bees in protected areas. Scientific Reports, 8, 9308. https://doi.org/10.1038/s41598-018-27591-y
Henry, M., \& Rodet, G. (2020). The apiary influence range: A new paradigm for managing the cohabitation of honey bees and wild bee communities. Acta Oecologica, 105, 103555. https://doi.org/10.1016/ j.actao.2020.103555

Kleiber, S. H. (2020). Rebuilding Detroit, hive by hive. In To the best of our knowledge. https://www.ttbook.org/interview/rebuilding-detroithive-hive

Kleijn, D., Biesmeijer, K., Dupont, Y. L., Nielsen, A., Potts, S. G., \& Settele, J. (2018). Bee conservation: Inclusive solutions. Science, 360, 389-390.

Kohák, E. (1984). The embers and the stars. University of Chicago Press.

Light, A. (2003). Urban ecological citizenship. Journal of Social Philosophy, 34, 44-63. https://doi.org/10.1111/1467-9833.00164

Lorenz, S., \& Stark, K. (2015). Saving the honeybees in berlin? A case study of the urban beekeeping boom. Environmental Sociology, 1, 116-126. https://doi.org/10.1080/23251042.2015.1008383

MacArthur, R. H. (1984). Geographical ecology: Patterns in the distribution of species. Princeton University Press.

Maderson, S., \& Wynne-Jones, S. (2016). Beekeepers' knowledges and participation in pollinator conservation policy. Journal of Rural Studies, 45, 88-98. https://doi.org/10.1016/j.jrurstud.2016. 02.015

Mallinger, R. E., Gaines-Day, H. R., \& Gratton, C. (2017). Do managed bees have negative effects on wild bees?: A systematic review of the literature. PLoS ONE, 12, e0189268. https://doi.org/10.1371/journal. pone. 0189268

Markolf, S. A., Chester, M. V., Eisenberg, D. A., Iwaniec, D. M., Davidson, C. I., Zimmerman, R., Miller, T. R., Ruddell, B. L., \& Chang, H. (2018). Interdependent infrastructure as linked social, ecological, and technological systems (SETSs) to address lock-in and enhance resilience. Earth's Future, 6, 1638-1659. https://doi.org/10.1029/2018E F000926

McCune, F., Normandin, É., Mazerolle, M. J., \& Fournier, V. (2019). Response of wild bee communities to beekeeping, urbanization, and flower availability. Urban Ecosystems, 23(1), 39-54. https://doi. org/10.1007/s11252-019-00909-y

McPhearson, T., Pickett, S. T. A., Grimm, N. B., Niemelä, J., Alberti, M., Elmqvist, T., Weber, C., Haase, D., Breuste, J., \& Qureshi, S. (2016). Advancing urban ecology toward a science of cities. BioScience, 66(3), 198-212. https://doi.org/10.1093/biosci/biw002

Meenar, M. R., \& Hoover, B. M. (2012). Community food security via urban agriculture: Understanding people, place, economy, and accessibility from a food justice perspective. Journal of Agriculture, Food Systems, and Community Development, 3, 143-160. https://doi. org/10.5304/jafscd.2012.031.013

Melathopoulos, A. P., Cutler, G. C., \& Tyedmers, P. (2015). Where is the value in valuing pollination ecosystem services to agriculture? Ecological Economics, 109, 59-70.

Melathopoulos, A., Rodia, M., Holt, J., \& Sagili, R. R. (2018). Residential beekeeping: Best-practice guidelines for nuisance-free beekeeping in oregon. Oregon State University Extension Service. https://catalog. extension.oregonstate.edu/em9186/html

Montambault, J. R., Dormer, M., Campbell, J., Rana, N., Gottlieb, S., Legge, J., Davis, D., \& Chakaki, M. (2018). Social equity and urban nature conservation: Social equity urban nature conservation. Conservation Letters, 11, e12423. https://doi.org/10.1111/conl.12423

Moore, L. J., \& Kosut, M. (2013). Buzz: Urban beekeeping and the power of the bee. NYU Press.

Nessen, S. (2012). Two years after legalized beekeeping, city may be running short on forage. WNYC.

Ollerton, J., Winfree, R., \& Tarrant, S. (2011). How many flowering plants are pollinated by animals? Oikos, 120, 321-326. https://doi. org/10.1111/j.1600-0706.2010.18644.x

Orr, D. W. (1990). Environmental education and ecological literacy. The Education Digest, 55, 49. 
Peck, D. T., \& Seeley, T. D. (2019). Mite bombs or robber lures? The roles of drifting and robbing in varroa destructor transmission from collapsing honey bee colonies to their neighbors. PLoS ONE, 14, e0218392. https://doi.org/10.1371/journal.pone.0218392

Pickett, S. T. A., Cadenasso, M. L., Childers, D. L., Mcdonnell, M. J., \& Zhou, W. (2016). Evolution and future of urban ecological science: Ecology in, of, and for the city. Ecosystem Health and Sustainability, 2, e01229. https://doi.org/10.1002/ehs2.1229

Pollan, M. (2006). The omnivore's dilemma: A natural history of four meals. Penguin.

Ropars, L., Dajoz, I., Fontaine, C., Muratet, A., \& Geslin, B. (2019). Wild pollinator activity negatively related to honey bee colony densities in urban context. PLoS ONE, 14, e0222316. https://doi.org/10.1371/ journal.pone.0222316

Rosan, C. D., \& Pearsall, H. (2017). Growing a sustainable city?: The question of urban agriculture. University of Toronto Press.

Rosenzweig, M. L. (2003). Win-win ecology: How the earth's species can survive in the midst of human enterprise. Oxford University Press.

Saunders, M. E., Smith, T. J., \& Rader, R. (2018). Bee conservation: Key role of managed bees. Science, 360, 389. https://doi.org/10.1126/ science.aat1535

Schlosser, E. (2012). Fast food nation: The dark side of the All-American meal. Houghton Mifflin Harcourt.

Schmidt, J. O. (2014). Evolutionary responses of solitary and social hymenoptera to predation by primates and overwhelmingly powerful vertebrate predators. Journal of Human Evolution, 71, 12-19. https:// doi.org/10.1016/j.jhevol.2013.07.018

Sponsler, D. B., Grozinger, C. M., Hitaj, C., Rundlöf, M., Botías, C., Code, A., Lonsdorf, E. V., Melathopoulos, A. P., Smith, D. J., Suryanarayanan, S., Thogmartin, W. E., Williams, N. M., Zhang, M., \& Douglas, M. R. (2019). Pesticides and pollinators: A socioecological synthesis. Science of the Total Environment, 662, 1012-1027. https://doi.org/10.1016/j.scitotenv. 2019.01.016

Turo, K. J., \& Gardiner, M. M. (2019). From potential to practical: Conserving bees in urban public green spaces. Frontiers in Ecology and the Environment, 282, 20142849. https://doi.org/10.1002/fee.2015
USDA-NASS. (2018). Annual honey report. https://downloads.usda. library.cornell.edu/usda-esmis/files/hd76s004z/bk128d542/x633f 346j/Hone-03-14-2018.pdf

van Dooren, T., Kirksey, E., \& Münster, U. (2016). Multispecies studies: Cultivating arts of attentiveness. Environmental Humanities, 8, 1-23. https://doi.org/10.1215/22011919-3527695

Vanengelsdorp, D., Evans, J. D., Saegerman, C., Mullin, C., Haubruge, E., Nguyen, B. K., Frazier, M., Frazier, J., Cox-Foster, D., Chen, Y., Underwood, R., Tarpy, D. R., \& Pettis, J. S. (2009). Colony collapse disorder: A descriptive study. PLoS ONE, 4, e6481. https://doi. org/10.1371/journal.pone.0006481

Walker, B., Holling, C. S., Carpenter, S., \& Kinzig, A. (2004). Resilience, adaptability and transformability in social-ecological systems. Ecology and Society, 9(2), 5. https://www.ecologyandsociety.org/vol9/iss2/ art5/

Willmer, P. G., Cunnold, H., \& Ballantyne, G. (2017). Insights from measuring pollen deposition: Quantifying the pre-eminence of bees as flower visitors and effective pollinators. Arthropod-Plant Interactions, 11(3), 411-425. https://doi.org/10.1007/s11829-0179528-2

Wolch, J. (2002). Anima urbis. Progress in Human Geography, 26, 721-742. https://doi.org/10.1191/0309132502ph400oa

\section{SUPPORTING INFORMATION}

Additional supporting information may be found online in the Supporting Information section.

How to cite this article: Sponsler DB, Bratman EZ. Beekeeping in, of or for the city? A socioecological perspective on urban apiculture. People Nat. 2021;3:550559. https://doi.org/10.1002/pan3.10206 